\title{
Forage Yield and Protein Content of Millo Blanco (Sorghum bicolor) and Two $\mathbf{F}_{1}$ Hybrids $^{1}$
}

\author{
A. Sotomayor-Ríos and L. Telek ${ }^{2}$
}

\begin{abstract}
Millo blanco (MB), Sorghum bicolor (L.) Moench, and two $F_{1}$ hybrids (Redlan $\times \mathrm{MB}$ and CK-60 $\times$ MB) were compared for yields of green forage (GF), dry forage (DF), crude protein (CP) content, CP yield, and height at Isabela, Puerto Rico. Six cuttings were made, the first, 58 days after planting and the remaining five, approximately every 30 days. The first harvest produced the highest forage yields. Dry forage yields (DFY) of $7,700 \mathrm{~kg} / \mathrm{ha}$ produced by CK-60 $\times \mathrm{MB}$ were $27.3 \%$ more than those of the male parent. The CP content of the three genotypes 58 days after planting was about $16 \%$ and crude protein yield (CPY) of 1,362 kg/ha was observed on CK-60 $\times$ MB, $33 \%$ more than that of MB. Although forage yields of the three genotypes were reduced at 30-day harvest intervals, the $\mathrm{CP}$ remained high and mean values of $18 \%$ were obtained.

The GFY of Redlan $\times$ MB $(118,519 \mathrm{~kg} / \mathrm{ha})$ during the 211-day growing period was $16.6 \%$ higher $(P<.05)$ than that of the male parent MB.

CK-60 $\times$ MB had $18.7 \%$ more DFY and $21.2 \%$ CPY than MB $(P<.05)$. No significant differences in height and $\mathrm{CP}$ content were observed among the three genotypes. The forage yields and high $\mathrm{CP}$ content obtained on $\mathrm{MB}$ and the two $F_{1}$ hybrids were excellent. The results indicate that these genotypes, especially the MB $F_{1}$ hybrids, are potentially good forage crops for Puerto Rico.
\end{abstract}

\section{INTRODUCTION}

Millo blanco (Sorghum bicolor (L.) Moench) has been used for silage and soilage (green-chop) in the southern part of Puerto Rico for many years. ${ }^{3}$ Records are not available as to its introduction into Puerto Rico nor is it known how long this plant has been under cultivation on the island. Millo blanco (MB) is a well adapted variety, highly resistant to drought, and produces excellent yields comparable to the best forage species in Puerto Rico. Under high moisture conditions and with nitrogen applications of approximately $134 \mathrm{~kg} / \mathrm{ha}$, Vázquez et al. ${ }^{3}$ reported dry forage yields (DFY) of over $39,000 \mathrm{~kg} / \mathrm{ha}$ in the Lajas Valley.

MB is a short-day plant. If planted in September in Puerto Rico, it will bloom early in November; if planted after the second week of January, it will also bloom in November. Its forage yields are reduced during the flowering period. This short-day plant characteristic of MB or any other

${ }^{1}$ Manuscript submitted to Editorial Board September 30, 1976.

${ }^{2}$ Research Geneticist and Chemist, respectively, Mayagüez Institute of Tropical Agriculture, Agricultural Research Service, USDA, Mayagüez, P.R.

${ }^{3}$ Vázquez, R., Eschenwald-Hess, A., and Martínez-Luciano, M. J., Response of native white sorghum to irrigation under different nitrogen-fertility levels and seeding rates in Lajas Valley, P.R., J. Agric. Univ. P.R. 50: 73-112, 1966. 
good forage could be of advantage to farmers if managed properly. A maximum utilization of the plant must be made during the nonflowering period when the plant produces its highest yields.

Although MB produces excellent yields and is highly resistant to the major diseases affecting forage sorghums in Puerto Rico, no attempt has been made to evaluate this species alone or. in hybrid combinations as to its nutritive value and dry forage potential.

This study compares the forage dry matter and protein content of MB with those of two of its $F_{1}$ hybrids when growing under long days in Puerto Rico before beginning of its flowering period.

\section{MATERIALS AND METHODS}

The experiment was conducted at the Isabela Experiment Farm of the Mayagüez Institute of Tropical Agriculture (MITA), ARS-USDA, located about $128 \mathrm{~m}$ above sea level with temperatures ranging from $18^{\circ}$ to $31^{\circ} \mathrm{C}$. The soil is a Coto clay (Oxisol) with a $\mathrm{pH}$ of approximately 5.8 . All plots were fertilized with a complete fertilizer (15-5-10) at the rate of 446 $\mathrm{kg} / \mathrm{ha}$ prior to planting.

MB, as male parent, was crossed to two well-known cytoplasmic male sterile A-lines of grain sorghum, CK-60 (A-3197) and Redlan (A-378). Field plots of the two $F_{1}$ hybrids (CK- $60 \times$ MB and Redlan $\times$ MB) and MB were established with a Farmall ${ }^{4}$ tractor on April 14, 1975. Seeding rate was approximately $15-20$ seeds $/ \mathrm{m}$. and after emergence the plants were thinned to about $10 \mathrm{~cm}$ between plants.

The experiment design was a complete block with five replications. Plots consisted of two rows spaced $101 \mathrm{~cm}$ apart and $6 \mathrm{~m}$ in length. Sampling area was $4.08 \mathrm{~m}^{2}$. The first cutting was made 58 days after planting, on June 10, 1975; subsequent harvests were made approximately every 30 days thereafter. The experiment was discontinued after the 6th harvest when the plants began to flower. After each cutting and throughout the duration of the experiment, $\mathrm{N}$ at the rate of about $56 \mathrm{~kg}$ / ha in a 15-5-10 analysis was applied to all plots. Overhead irrigation was applied whenever necessary.

Before each cutting, average height from the ground to the tip of the longest leaf of 2 plants/row chosen at random from each plot was measured on all treatments. Green forage yields/plot were calculated for each harvest. Samples were analyzed for dry forage and protein content at the MITA laboratories.

\footnotetext{
${ }^{4}$ Trade names are used in this publication solely for the purpose of providing specific information. Mention of a trade name does not constitute a guarantee or warranty of equipment or materials by the Agricultural Experiment Station of the University of Puerto Rico or an endorsement over other equipment or materials not mentioned.
} 
TABLE 1. - Mean green forage, dry matter, crude protein, crude protein yield, and height in Millo blanco and two $F_{1}$ hybrids at six different harvest periods ${ }^{1}$

\begin{tabular}{|c|c|c|c|c|c|}
\hline & $\begin{array}{c}\text { Green forage } \\
\text { yield }\end{array}$ & Dry forage yield & $\begin{array}{l}\text { Crude pro- } \\
\text { tein }\end{array}$ & $\begin{array}{l}\text { Crude protein } \\
\text { yield }\end{array}$ & Height \\
\hline & $\bar{K} g / h a$ & $\bar{K} g / h a$ & $\%$ & $K g / h a$ & $\mathrm{Cm}$ \\
\hline \multicolumn{6}{|c|}{ Harvest 1 (58 days) } \\
\hline $\begin{array}{r}\text { Redlan } \times \text { MB } \\
\mathrm{CK}-60 \times \mathrm{MB} \\
\mathrm{MB}\end{array}$ & $\begin{array}{l}61,676 \mathrm{a} \\
60,885 \mathrm{ab} \\
50,720 \mathrm{c}\end{array}$ & $\begin{array}{l}6,745 \mathrm{~b} \\
7,700 \mathrm{a} \\
5,568 \mathrm{~b}\end{array}$ & $\begin{array}{l}16.68^{2} \\
15.60 \\
16.42\end{array}$ & $\begin{array}{r}1,162.1 \mathrm{~b} \\
1,362.2 \mathrm{a} \\
908.9 \mathrm{~b}\end{array}$ & $\begin{array}{l}263^{2} \\
262 \\
259\end{array}$ \\
\hline \multicolumn{6}{|c|}{ Average of harvests 2 to 6} \\
\hline Redlan $\times$ MB & 11,369 & 2,018 & 18.05 & 383.5 & 142 \\
\hline $\mathrm{CK}-60 \times \mathrm{MB}$ & 11,289 & 1,995 & 17.99 & 361.7 & 143 \\
\hline MB & 9,637 & 1,719 & 17.98 & 317.6 & 137 \\
\hline
\end{tabular}

${ }^{1}$ Means within a column with the same letter or letters in common do not differ significantly at $(\mathrm{P}<.05)$ by Duncan's multiple range test.

${ }^{2}$ Nonsignificant.

\section{RESULTS AND DISCUSSION}

Table 1 shows the average GF, DF, CP content, CP yield, and height of MB and the two $F_{1}$ hybrids CK- $60 \times$ MB and Redlan $\times$ MB for harvest 1 and the average of harvests 2 to 6 . In the first cutting, 58 days after planting, no significant differences were noted between Redlan $\times$ MB and $\mathrm{CK}-60 \times \mathrm{MB}$ in GF/ha. The two $\mathrm{F}_{1}$ hybrids outyielded $\mathrm{MB}(\mathrm{P}<$ $.05)$. The highest DF yielder was $\mathrm{CK}-60 \times \mathrm{MB}$ with $7,700 \mathrm{~kg} / \mathrm{ha}$. This $\mathbf{F}_{\mathbf{1}}$ hybrid produced $27.3 \%$ more DM than its male parent $(\mathrm{P}<.05)$. The $\mathrm{CP}$ content of the two $F_{1}$ hybrids and $M B$ ranged from 15.60 to 16.68. Mean differences were not significant. The CPY of CK- $60 \times \mathrm{MB}$ were significantly superior to those of Redlan $\times \mathrm{MB}$ and MB $(\mathrm{P}<.05)$. CK $-60 \times \mathrm{MB}$ produced 33\% more CPY than MB. The CP content of the three genotypes were higher than those reported for the best grasses in Puerto Rico when harvested at about 60 days. ${ }^{5}$

Figure 1 shows the DFY, and CPY of the three genotypes when cut at $58,30,32,30,29$ and 32 days. Forage and protein yields were drastically reduced compared with those of the first cutting. The CP content of the three genotypes remained high, and mean values of over $18 \%$ were obtained.

Table 2 shows the total GFY, DFY, CP, CPY, and height of MB and its two $\mathrm{F}_{1}$ hybrids during the 211-day growing period. The GFY of the two $\mathrm{F}_{1}$ hybrids were not significantly different. GFY were $16.6 \%$ higher

${ }^{5}$ Sotomayor-Ríos, A., Juliá, F. J., and Arroyo-Aguilú, J. A., Effects of harvest intervals on the yield and composition of 10 forage grasses, J. Agric. Univ. P.R. 58: 448$55,1974$. 
YIELD AND PROTEIN CONTENT OF SOME SORGHUM FORAGES 303
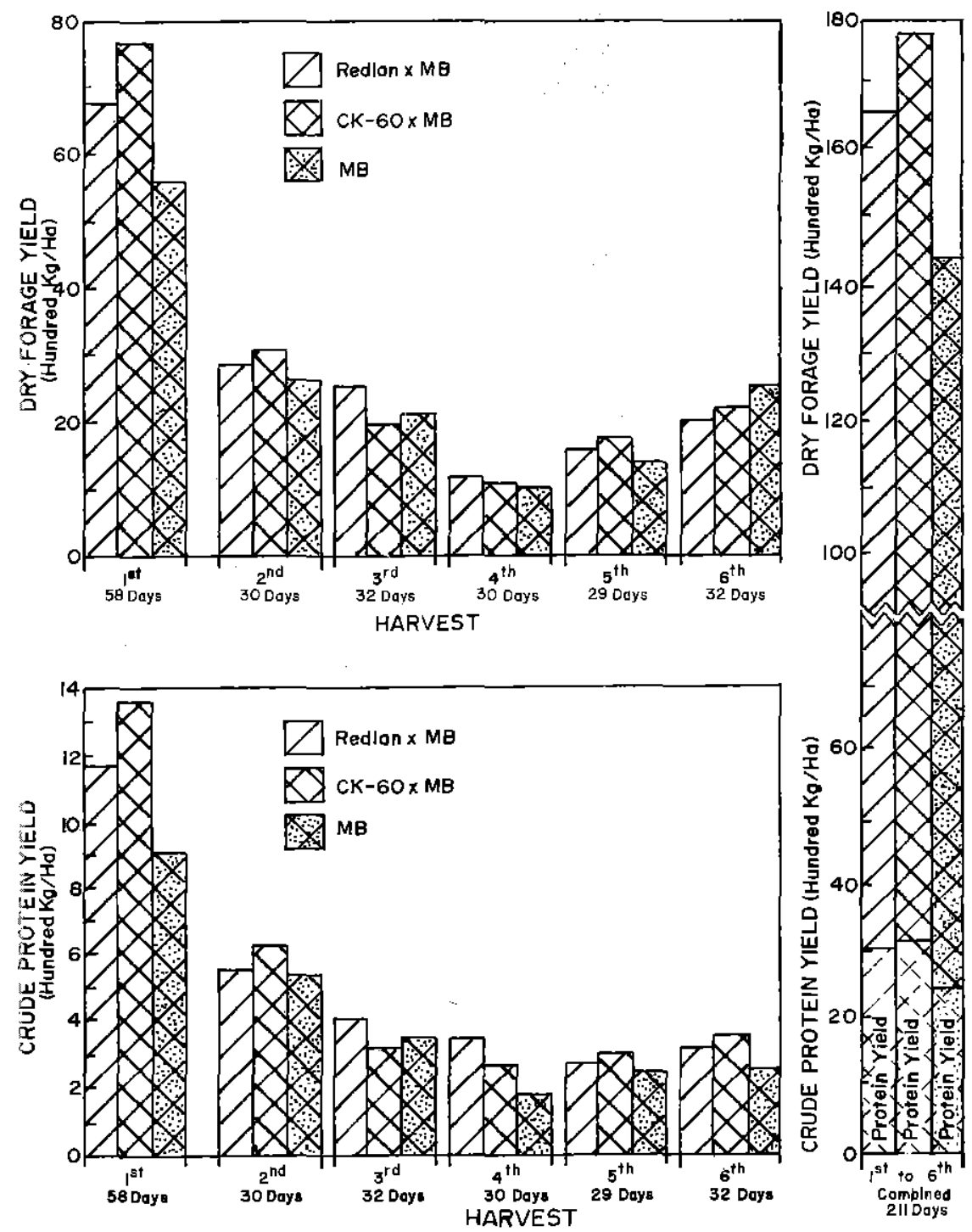

FIG. 1. - Dry matter and crude protein yields of Millo blanco (MB), Redlan $\times$ MB and CK $-60 \times \mathrm{MB}$ cut every $58,30,32,30,29$, and 32 days, respectively, at Isabela, Puerto Rico.

$(\mathrm{P}<.05)$ in Redlan $\times \mathrm{MB}$ as compared to the corresponding male parent.

The difference in DFY of the two $\mathrm{F}_{1}$ hybrids was not statistically significant. The highest producer was CK-60 $\times$ MB and had $18.7 \%$ more 
TABLE 2. - Yield, protein content, and height in Millo blanco and two $F_{1}$ hybrids during a 211 day period 1

\begin{tabular}{rrrrrr}
\hline & $\begin{array}{c}\text { Green forage } \\
\text { yield }\end{array}$ & Dry forage yield & $\begin{array}{c}\text { Crude pro- } \\
\text { tein }\end{array}$ & $\begin{array}{c}\text { Crude protein } \\
\text { yield }\end{array}$ & Height \\
\hline & $K g / h a$ & $K g / h a$ & $\%$ & $K g / h a$ & $C m$ \\
Redlan $\times$ MB & $118,519 \mathrm{a}$ & $16,639 \mathrm{a}$ & 17.82 & $3,079.7 \mathrm{a}$ & $186^{2}$ \\
CK-60 $\times$ MB & $117,329 \mathrm{a}$ & $17,674 \mathrm{a}$ & 17.60 & $3,170.7 \mathrm{a}$ & 163 \\
$\mathrm{MB}$ & $98,904 \mathrm{~b}$ & $14,362 \mathrm{~b}$ & 17.71 & $2,497.1 \mathrm{~b}$ & 157 \\
\hline
\end{tabular}

${ }^{1}$ Means within a column with the same letter or letters in common do not differ significantly at $(\mathrm{P}<.05)$ by Duncan's multiple range test.

${ }^{2}$ Nonsignificant.

DFY than the corresponding male parent. The CP content of the three genotypes was approximately $18 \%$. There were no significant differences among those means. The CPY of the two $F_{1}$ hybrids were not significantly different. The best CPY producer was CK-60 $\times$ MB with 3,170 $\mathrm{kg} / \mathrm{ha}$. Those yields were $21.2 \%$ higher $(\mathrm{P}<.05)$ than yields of the male parent.

The high forage yields produced by Millo blanco, CK-60 $\times \mathrm{MB}$ and Redlan $\times \mathrm{MB}$, especially in the first cutting, 58 days after planting, could be an important factor to consider as to the selection of this species. Even the most aggressive forage grasses in the tropics, such as those in the genera Cynodon, Brachiaria, Digitaria, and others, require about 2 to 5 months of growth before light grazing or cutting is initiated. The results of this experiment show that forage sorghums such as Millo blanco or its $F_{1}$ hybrids may offer great potential for rapid utilization after planting due to their high yields and excellent CP content.

\section{RESUMEN}

Millo Blanco (MB), Sorghum bicolor (L.) Moench, y dos híbridos $\mathrm{F}_{1}$ (Redlan $\times$ MB y CK-60 $\times \mathrm{MB}$ ) se evaluaron en términos de forraje verde (GF), materia seca (DF), proteína bruta (CP), y altura durante 211 días en Isabela, Puerto Rico. Se Ilevaron a cabo seis cortes, el primero a los 58 días y los subsiguientes cada 30 días, aproximadamente.

La producción de forraje verde (GFY) del primer corte fluctuó entre 61,676 y 50,720 $\mathrm{kg}$./ha. La producción de materia seca (DFY) del híbrido CK-60 $\times$ MB de $7,700 \mathrm{~kg} . / \mathrm{hg}$. fue $27.3 \%$ mayor que la de MB $(\mathrm{P}<.05)$. La $\mathrm{CP}$ de los tres genotipos fue de aproximadamente $16 \%$ y no se observaron diferencias significativas entre ellos. La producción de proteína bruta (CPY) de CK-60 × MB fue de 1, 1,362 kg./ha., $33 \times$ mayor que la de MB $(\mathrm{P}<.05)$.

La GFY del híbrido Redlan $\times$ MB durante el período total de 211 días fue de 118,519 $\mathrm{kg} . /$ ha., approximadamente $16.6 \%$ mayor $(\mathrm{P}<.05)$ que la de MB. El híbrido CK $-60 \times$ MB produjo $17,674 \mathrm{~kg} . / \mathrm{ha}$.; aproximadamente $18 \%$ más materia seca que $\mathrm{MB}(\mathrm{P}<.05)$. El contenido de CP de los tres genotipos durante el período de 211 días fue excelente (aproximadamente 18\%). 